\title{
TELENOVELAS BRASILEIRAS CRIANDO IMAGENS E IMAGINÁRIOS TURÍSTICOS: O CASO DO DESTINO RIO GRANDE DO NORTE
}

\author{
BRAZILIAN SOAP OPERAS CREATING TOURISTIC IMAGES AND \\ IMAGERY: THE CASE OF THE TOURIST DESTINATION OF RIO \\ GRANDE DO NORTE
}

\author{
TELENOVELAS BRASILEÑAS CREANDO IMÁGENES E \\ IMAGINARIOS TURÍSTICOS: EL CASO DEL DESTINO RIO \\ GRANDE DO NORTE
}

\author{
ADRIELLY FLORÊNCIO DE LIMA \\ Graduada em Turismo pela UFRN (Campus Natal - RN - Brasil) \\ GERENTE DA VIAÇÃO FLORENTUR \\ adriellyflorencio@gmail.com \\ http://orcid.org/0000-0002-6122-8784 \\ MICHEL JAIRO VIEIRA DA SILVA \\ Doutor em Turismo pelo PPGTUR/ UFRN \\ Professor Adjunto do Departamento de Turismo da UFRN \\ micheljvs@hotmail.com \\ http://orcid.org/0000-0002-9649-8063
}

Licença CC BY:

Artigo distribuído

sob os termos

Creative Commons,

permite uso

e distribuição

irrestrita em

qualquer meio

desde que o autor

credite a fonte

original.

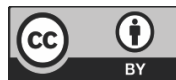

DATA DE SUBMISSÃO: 25/08/2017 DATA DE ACEITE: 10/09/2018

RESUMO: O uso de produções audiovisuais televisivas para promoção de destinos no Brasil tem sido uma ferramenta importante, principalmente pelo alcance ainda forte da TV. E quando se trata do uso de telenovelas (que tem tradição em criação e exportação), a aparição de destinos turísticos na trama se torna relevante na publicização e na criação de imaginários turísticos. Diante disso, o estudo buscou apresentar os elementos que compõem a imagem e o imaginário turístico do destino Rio Grande do Norte a partir das telenovelas da Rede Globo e do SBT (1986-2016). Metodologicamente, o trabalho faz uma abordagem qualitativa, desenvolvendo análise documental e de conteúdo fílmico de oito telenovelas gravadas no RN. Os resultados apontam para a construção de imaginário que nem sempre remete ao estado (apenas como cenário não identificado), já que algumas telenovelas não divulgam o nome do destino. $\mathrm{E}$ quando enfatizam se passar no estado, evidenciam um destino de motivação sol e praia, com poucos elementos culturais e históricos, com foco principalmente em casais em programação romântica, com pequenos elementos de aventura. Conclui-se que tal ferramenta se consolida como uma importante maneira de divulgação do destino RN, entretanto limita o imaginário do estado, que deveria diversificar a publicização de sua oferta. 
PALAVRAS-CHAVE: Turismo. Telenovela. Rio Grande do Norte.

ABSTRACT: The use of television audiovisual productions to promote destinations in Brazil has been an important tool, especially for the still strong reach of TV. And when it comes to the use of soap operas (which has a tradition of creating and exporting to other nations), the appearance of tourist destinations as a background to the plot is important for the publicity and creation of tourist images and imagery. This study presents the elements that make up the touristic image and imagery of the destination of Rio Grande do Norte, in the soap operas aired on the TV channels Rede Globo and SBT (1986-2016). In terms of methods, this work uses a qualitative approach, with analysis of documents and the filmed content of eight soap operas recorded in the city. The results indicate the construction of an imaginary that does not always refer to the state (except as an unidentified scenario), since some soap operas do not give the name of the destination. And when they do emphasize their presence in the state, the productions portray images of sun, sea and sand, with little mention of the cultural and historical elements, and a focus mainly on couples in romantic scenes, with a few elements of adventure. It is concluded that this tool is consolidated as an important means of publicizing the destination of Rio Grande do Norte, but it can limit the public image of the state, which should diversify the ways in which it advertises its offer.

KEYWORDS: Tourism. Soap Opera. Rio Grande do Norte.

RESUMEN: El uso de producciones audiovisuales televisivas para promoción de destinos en Brasil ha sido una herramienta importante, principalmente por el alcance aún fuerte de la TV. Y cuando se trata del uso de telenovelas (que tiene tradición en creación y exportación), la aparición de destinos turísticos en la trama se vuelve relevante en la publicidad y en la creación de imaginarios turísticos. El estudio buscó presentar los elementos que componen la imagen e imaginario turístico del destino Rio Grande do Norte a partir de las telenovelas de las emisoras Globo y SBT (1986-2016). Metodológicamente, el trabajo hace un enfoque cualitativo desarrollando análisis documental y de contenido fílmico de ocho telenovelas grabadas en el estado de RN. Los resultados apuntan a la construcción de imaginario que no siempre remite al estado (apenas como escenario no identificado), ya que algunas telenovelas no divulgan el nombre del destino. Y cuando enfatizan si pasan en el estado, evidencian un destino de motivación sol y playa, con pocos elementos culturales e históricos, con foco principalmente en parejas en programación romántica, con pequeños elementos de aventura. Se concluye que tal herramienta se consolida como una importante manera de divulgación del destino RN sin embargo, limita el imaginario del estado, que debería diversificar la publicidad de su oferta.

PALABRAS CLAVE: Turismo. Telenovela. Rio Grande do Norte.

\section{INTRODUÇÃO: TURISMO NA SUA TELINHA}

No decorrer do tempo, o turismo vem se destacando como atividade com impactos no campo social, ambiental, cultural, tendo sua relevância apresentada principalmente em seu viés econômico. De acordo com o WTTC (2015), a contribuição total do setor de turismo para o produto interno bruto (PIB) global correspondeu a 9,8\% em 2015. Sempre associada a esse crescimento da atividade nas últimas décadas, está a criação dos imaginários que alimentam essa prática turística, com o uso das imagens vindas, por exemplo, da promoção de destinos por meio da informação formal, como em jornais, programas esportivos, de variedades e por meio de linguagem de entretenimento como a literatura, vídeos em redes sociais, música, cinema e telenovela.

No que se refere a essa última linguagem, com o grande poder de estimular para o consumo, e considerando a repercussão que a telenovela tem no Brasil, é importante compreender o fenômeno que faz com que o telespectador se torne capaz de se deslocar 
do seu lugar de origem, influenciado pela telenovela e suas narrativas fictícias. Obra essa capaz de motivar as pessoas a viajar, buscando repetir as experiências dos personagens, como também descobrir mais sobre a cultura, a paisagem, os costumes e os atrativos turísticos de um determinado lugar exibido na tela.

Como destino turístico, o estado do Rio Grande do Norte foi cenário de algumas telenovelas dentro das principais emissoras do Brasil, sobretudo a Rede Globo e o SBT. Tomando como base essa exibição nacional (como também internacional) que permite e auxilia na construção imagética e imaginária do estado, realizou-se este trabalho abordando uma temática ainda pouco explorada nos estudos turísticos nacionais.

Entendendo que a telenovela é uma ficção, os que a assistem criam suas impressões sobre o destino de acordo com o que é transmitido, criando imaginários sobre a experiência turística. De acordo com Cunha (2011, p. 38), "a noção de imaginário surge em relação a tudo que se apreende visualmente do mundo e é elaborado coletivamente". Na contemporaneidade, o imaginário coletivo pode ser edificado em redes sociais, em matérias jornalísticas ou devido à aparição em telenovelas de grande audiência.

Assim como outras linguagens, a telenovela, como construtora de imaginários, atua como um intermédio entre os espectadores e a realidade, representa de certa maneira o cotidiano do brasileiro e seus anseios, conflitos e valores essenciais. Em muitos casos, apesar de caráter fictício, essa obra convida à reflexão e oferece um retrato momentâneo do país. Ou seja, a telenovela cria quadros imagéticos em cenas ficcionais, mas que permitem ao telespectador associá-las à sua realidade (Kanyat, 2014, p. 55).

Conforme Hamburger (2005), "telenovelas são quase tão antigas quanto à televisão no Brasil. Nos últimos 50 anos, o gênero vem acompanhando as transformações tecnológicas, políticas, sociais e culturais que marcaram a história do País". No turismo, a telenovela (assim como o cinema, e outras linguagens) tornou-se uma ferramenta de divulgação (merchandising). Com a aparição do destino em cena, o espectador sintetiza as imagens exibidas e constrói imaginário daquele local, interessando-se em visitá-lo. De acordo com a Pesquisa Brasileira de Mídia (2015), 95\% dos brasileiros costumam assistir à programação de TV, desses, 73\% acessam diariamente, recebendo informação que constroem imaginários também sobre destinos diversos.

Caminhos das Índias (2009) foi uma telenovela da Rede Globo cuja parte da trama era centrada no Rajastão (principal estado da Índia). As imagens exibidas no decorrer das cenas retratavam a sua cultura, arquitetura e belezas naturais, fazendo com que o telespectador conhecesse atrativos e criasse um imaginário turístico sobre o pais. Tal obra levou muitos brasileiros a buscarem agências de viagens com o propósito de visitar a Índia. O mesmo acontece em outras telenovelas que enfatizaram destinos internacionais e nacionais, tais como: O Clone (2001), que se passava em Marrocos; Salve Jorge (2012), na Turquia; Pantanal (1990), no estado de Mato Grosso; Da cor do pecado (2004), nos lençóis maranhenses e centro histórico de São Luís; Além do tempo (2015), com cenários da Serra Gaúcha; e $O$ Outro Lado do Paraíso (2017), descortinando o Jalapão de Tocantins.

Contando com essa realidade do uso das telenovelas na divulgação de destinos, este artigo tem como objetivo principal apresentar os elementos que compõem a imagem e o imaginário turístico do destino Rio Grande do Norte a partir das telenovelas da Rede Globo e SBT (1986-2016). Para garantir o alicerce de tal objetivo, a pesquisa buscou identificar 
telenovelas e elencar os cenários, além de apresentar os atributos turísticos explícitos e implícitos nas cenas novelísticas.

Para tanto, será necessário apresentar a seguir um referencial teórico vinculado aos conceitos de imagem e imaginário e marketing turístico, seguido de apresentação de trajetória metodológica (analise documental e de conteúdo fílmico), seguido de análise dos dados alimentando os objetivos específicos do artigo, culminando com considerações finais.

\section{REFERENCIAL TEÓRICO: IMAGEM E IMAGINÁRIO TURÍSTICO NESSE CANAL}

Imagens porque, na própria cidade ou no estrangeiro, antes de se deslocarem para um novo lugar, as pessoas já terão entrado em contato com ele visualmente, por meio de fotos em jornais, folhetos, cenas de filmes (de telenovelas) (...). Imaginários porque as pessoas terão sentimentos, alimentados por amplas e diversificadas redes de informação, que as levarão a achar um local romântico, outro perigoso, outro bonito, outro civilizado. A esses sentimentos construídos em relação a locais e objetos e pessoas temos chamado de imaginário. (Gastal, 2005, p. 13 - parênteses nosso)

Desde muito cedo, a construção e o uso da imagem têm contribuído com o avanço das formas de expressão do homem. Isso porque uma das primeiras formas de comunicação social que se conhecia até então foram as pinturas rupestres, as quais podem ser encontradas em diversas partes do mundo. Segundo os historiadores, ainda se tem muita dificuldade em afirmar com exatidão o significado e a função dessas imagens. Acredita-se que tais imagens eram feitas para expressar sentimentos, culturas ou até mesmo para alertar sobre questões práticas, legitimar discursos, interesses e normas. Desde então, a imagem alimenta e é alimentada pela "soma de crenças, ideias e impressões que uma pessoa tem de um objeto" (Kotler; Fox, 1994, p. 59), nesse caso, de um espaço, de um destino turístico.

A imagem aqui se aplica a partir da simples percepção do indivíduo consumidor para com o que sua visão está recortando, acentuando, assimilando, recebendo como informação que suscitará no consumo de produto ou serviço turístico. Esse acesso à imagem se dá a partir de várias informações percebidas espontaneamente ou objetivamente. Existem na contemporaneidade inúmeras formas de reprodução das imagens. Pode-se encontrá-las nas obras literárias, figurativas, nas músicas, nas redes sociais, no cinema, nos programas televisivos, etc. Essas expressões e canais que possibilitam a propagação da imagem, quando auxiliados pela rápida repercussão que é oferecida pelos mesmos, ampliam a importância do uso dessas imagens pelos gestores de destinos turísticos.

Segundo o Ministério do Turismo (MTUR, 2016), "a imagem é um dos principais insumos para a venda dos destinos turísticos no Brasil. São as fotos de catálogos e guias de viagem, divulgadas em redes sociais e sites especializados que encantam o turista e o fazem visitar o extenso litoral brasileiro, conhecer as manifestações artísticas e o patrimônio cultural do país". As imagens neste caso expressam mensagens sobre o que se deve consumir, que lugar se deve visitar e de que maneira. E nesse campo "as produções audiovisuais acabam por se constituir no principal veículo de informação, ditando regras, valores, hábitos" (Nascimento, 2009, p.20) - e no caso do mercado turístico, influenciando nas decisões e nos estímulos para formar uma impressão - um imaginário sobre um destino que agora se deseja visitar. 
Nesse sentido, deve-se produzir uma imagem muitas vezes apoteótica (em muitos casos até perigosamente irreal e diferente da realidade) de um destino turístico, pois se cria um imaginário coletivo que apela para a decisão em viajar e reproduzir o que é indicado na imagem. $\mathrm{O}$ imaginário age no indivíduo na construção do "modelo mental a partir de descrições coerentes e determinadas de lugares" (Lévy, 1998, p. 128), objetos, pessoas. E de acordo com Durand (2002), o imaginário é uma espécie de reservatório de todas as imagens e vários outros aspectos que contribuem para a construção de uma percepção de mundo. Nesse sentido, segundo Marcon (apud Ashton, 2003, p. 125), ele "é uma configuração racional de imagens, decorrente de experiências e de realidade vividas, contextualizadas pelas características de cada um. Geramos um código simbólico próprio no inconsciente, uma coleção de imagens que vão sendo liberadas através da revisitação".

O imaginário turístico produzido a partir da exibição de imagens permite que se possa presumir o lugar como destino. O indivíduo idealiza o destino a partir do desejo, criando um plano de viagem. Graburn \& Gravari-Barbas (2011) afirmam que: "o imaginário dos lugares, dos destinos e das viagens, é consumido por diversas populações em todo o globo, notadamente por meio do papel crescente das mídias e das oportunidades de viajar".

A atividade turística é - entre outras coisas - um conjunto de ofertas que ocasiona uma experiência ao visitante. Para Kotler e Fox (1994, p. 24), "marketing envolve programar as ofertas da instituição para atender às necessidades e aos desejos de mercados-alvos, usando preço, comunicação e distribuição eficazes para informar, motivar e atender a esses mercados". Ou seja, até chegar o momento da realização e do desfrute da viagem, organizações e destinos desenvolvem todo um exercício de divulgação e de despertar no consumidor turista, o desejo de consolidar uma experiência de viagem. Isso passa por processo de conhecimento de público-alvo, encontro de canais de aproximação com esse turista e oferta de algo alinhado com suas condições e seus interesses turísticos (Middleton e Clark, 2002).

Dessa maneira, costumeiramente os gestores do destino turístico aplicam o marketing, a fim de impulsionar e fortalecer sua posição competitiva - essa cada vez mais necessária. A tecnologia e os canais diversos de comunicação são ferramentas fundamentais do marketing e da publicidade turística, estando a programação das emissoras de TV inseridas neste contexto - oferecendo imagens e construindo imaginários turísticos. Essa fórmula de uso de programas, nesse caso - de enredos telenovelísticos para fomentar destinos e convencer pessoas a deslocarse para esse ou aquele lugar - é antiga. Ela normalmente é estudada quando se destaca a prática do turismo cinematográfico (MTUR, 2007 - Albernaz, 2009¹) ou cineturismo (Nascimento, 2009). Esse que vem sendo amplamente teorizado e discutido, visto que entende o cinema como indutor de viagem (film-induced tourism - Macionis, 2004; Beeton, 2005).

Ao ver um lugar ou outro produto ser mostrado sutilmente em um filme, o espectador acaba absorvendo a ideia de que aquilo fora mostrado de forma espontânea, e acaba por querer consumi-lo também. Os filmes ainda têm grande poder na construção da imagem de um lugar, pois quem está encarregado de produzir a obra audiovisual (diretor/roteirista) pode imprimir a imagem que quiser sobre esse lugar através de ferramentas

Prática turística de "conhecer as estruturas que abrigam as produções cinematográficas e os mecanismos que dão forma a este mundo de fantasia por meio de visitas aos estúdios e sets de filmagem; e o de conhecer os destinos e cenários (locações) onde a narrativa do filme se sucedeu, na tentativa de viver momentos e emoções criadas no filme e introjetadas no imaginário do espectador-turista" (Albernaz, 2009, p. 17). 
próprias do audiovisual, como o uso de trilha sonora, imagens tomadas de ângulos propositais e estratégicos, entre outros. (Pereira Neto e Schmidlin, 2013, p. 10)

Aceitando as telenovelas (espécie de television dramas - Iwashita, 2008) - assim como o cinema - como indutoras de viagem, é preciso reconhecer a audiência, o papel e a força da programação da TV brasileira no comportamento de consumo nacional. Segundo Mattos (2010), a TV instalou-se no Brasil em 1950, mais precisamente em estúdios de São Paulo, numa época em que o rádio era o meio de comunicação mais popular no Brasil. E quanto às telenovelas inseridas nessa programação:

Não resta dúvida de que constitui um exemplo de narrativa que ultrapassou a dimensão do lazer, que impregna a rotina cotidiana da nação, construiu mecanismos de interatividade e (...) se configura como uma experiência, ao mesmo tempo, cultural, estética e social (...) Os telespectadores se sentem participantes das novelas e mobilizam informações que circulam em torno deles no seu cotidiano. (Lopes, 2014, p. 4)

Acredita-se que já nas primeiras décadas a televisão popularizou-se entre os brasileiros, sendo a sua programação e as telenovelas propagadores importantes de comunicação de massa, com forte apelo também para difusão de imagens e construção de imaginários turísticos. De acordo com Bucci (1996, p. 25), "para os interessados na cena brasileira, a televisão tem sido o ambiente inevitável. Falar de TV, repito, é falar do Brasil". E falar desse Brasil na perspectiva turística é falar de crescimento econômico, enaltecendo essa ideia da imagem e do imaginário na telenovela como meio de divulgação da cultura e das paisagens dentro do próprio país, como também no mundo, favorecendo desenvolvimento turístico de diversas localidades.

Essa divulgação de destinos por meio das telenovelas pode ser caracterizada como merchandising. Essa técnica aplicada na obra televisiva "consiste na explicitação de um produto (marca ou serviço), seja pela referência explicita do personagem, seja pela sua posição estratégica no cenário, com vistas a influenciar o público e tentar transformá-lo em consumidor" (Castro, 2005). Reforça, assim, a imagem do destino na mente do telespectador.

A programação das telenovelas é líder em audiência desde os anos 1960. A partir delas, que tinham dois ou três capítulos exibidos por semana no ano de 1963, surgiu então mais uma maneira de despertar no telespectador uma experiência de viajar sem sair de casa e, mais do que isso, despertar a curiosidade e o encantamento sobre determinados lugares e coisas, gerando consumo e deslocamentos reais.

A primeira experiência de merchandising em telenovelas, segundo Trindade (1999), foi em Beto Rockfeller, exibida em 1968, em que o personagem tomava o antiácido efervescente Alka setzer da Bayer - o que virou um produto bastante vendido a partir disso. Essa fórmula foi aperfeiçoada, chegando a ter em uma única telenovela diversas peças de merchandising de produtos, serviços e comportamento turístico. A telenovela Senhora do Destino (2004), por exemplo, superou a marca de cem ações de merchandising no enredo.

Os produtos utilizados, os locais visitados e os comportamentos expressos pelos atores e atrizes nas telenovelas estimulam o telespectador a consumi-los. O novelista Walter Avancini (apud Trindade, 1999, p. 7) afirmou que: 
A televisão divulga pela publicidade produtos para a sociedade, a qual passa a buscar no seu cotidiano por estes mesmos produtos. A novela na sua linha dramática busca esta realidade de comportamento. Então ela não pode ser separada do merchandising.

Conclui-se então que, devido à forte influência que a telenovela possui sobre os brasileiros, o merchandising nesse meio de entretenimento é uma grande estratégia de comunicação. A divulgação das paisagens de um destino turístico exibidas numa telenovela gera um grande impacto de visibilidade. Essa visibilidade pode ser direta, quando o enredo enfatiza se tratar do destino - a telenovela Pantanal (1990) possuía cenas claramente ambientadas no bioma, o que permite ao turista uma fácil assimilação da imagem e da construção do imaginário turístico. Pode ocorrer também uma visibilidade indireta, quando se utilizam locações do destino, mas o enredo não retrata devidamente o lugar - cenas da telenovela $O$ Clone (2001) foram gravadas nas dunas de Jenipabu (RN), mas simulando o deserto marroquino. Nesse caso, a vantagem competitiva está nas matérias jornalísticas e publicitárias que movimentam o uso do espaço e a permanência de celebridades no destino.

Independentemente da forma de aparição do destino, o alcance midiático convence gestores de empreendimentos privados e secretarias municipais e estaduais de turismo no Brasil a investirem nessa estratégia - principalmente em momentos de alta audiência das telenovelas: primeiros e últimos capítulos. Em alguns casos, com o objetivo de promover o uso das locações para filmagens e oferecer incentivos para os produtores de TV e cinema, Film commissions ${ }^{2}$ estão sendo criadas em destinos brasileiros, a fim de captar produções audiovisuais (cinematográficas, televisivas ou publicitárias), difundir imagens e criar imaginários turísticos. Nesses casos são valorizados paisagens, pessoas e modo de vida (Macionis, 2004).

A preocupação em ofertar imagens e criar imaginários turísticos é fundamental no processo de planejamento de destinos, mas não deve ser maior do que o alinhamento entre o imaginário que se quer criar e a real oferta turística. O turismo é uma atividade que normalmente alimenta muitas expectativas, sonhos de consumo. Entretanto, quando a realidade não condiz com a expectativa (alimentada pelo imaginário), gera profunda frustração turística e uma grave desvantagem competitiva.

Tal frustração pode ocorrer quando o turista percebe que destinos turísticos apresentam uma experiência turística artificializada - próximo do imaginário sugerido (ou que reduzem seu potencial de imaginário a poucas imagens, criando percepções limitadas), mas distante da realidade local. Nesse caso, o que se oferece para o turista é um lugar fictício (um pseudo-lugar - Cruz, 2007) imerso em uma bolha, um gueto, um enclave e com uma dinâmica díspar ou distanciada da vivida pelos residentes e com um aspecto fake. Em outros casos, o imaginário edificado pelas telenovelas é apoteótico demais, à medida que a experiência de visita pouco ou em nada corresponde ao sugerido no enredo.

2 As Film Commissions são órgãos públicos, privados ou criados a partir de parcerias público-privadas, estruturadas regional e/ou nacionalmente para fomentar e facilitar a produção e o desenvolvimento do audiovisual das regiões que representam. Geralmente estas entidades atuam buscando atrair produções audiovisuais, promovendo as vantagens competitivas regionais e organizando os serviços de apoio e de negociações com a burocracia governamental (BRASIL, 2007, p. 16). 
Dessa maneira, é importante que a aparição de destinos em telenovelas deva ser minuciosamente pensada e alinhada com o segmento, com a oferta turística e a realidade do destino - enaltecendo certamente seus diferenciais e potencialidades, mas de forma a valorizar a diversidade da oferta, a qualidade dos serviços, além de seus traços culturais, tradições e realidade citadina, litorânea ou rural.

\section{METODOLOGIA: BUSCANDO O MELHOR ENQUADRAMENTO}

Esta pesquisa é do tipo qualitativa exploratória-descritiva, realizando uma análise documental sobre sinopse e curiosidades das novelas, sendo a fonte os centros de catalogação e imagem das emissoras Rede Globo e SBT, seguida de uma análise de conteúdo fílmico, a partir de cenas de telenovelas filmadas no Estado do RN. Nessa abordagem, a pesquisa avança na apreciação descritiva de enredos, cenas e contextos impressos nas telenovelas (Quadro 1) a seguir selecionadas:

Quadro 1 - Telenovelas com cenas filmadas no RN

\begin{tabular}{|c|c|c|c|c|}
\hline Telenovela & Ano & Emissora & Autoria & Enredo \\
\hline Cambalacho & 1986 & $\begin{array}{l}\text { Rede } \\
\text { Globo }\end{array}$ & $\begin{array}{l}\text { Sílvio de } \\
\text { Abreu }\end{array}$ & $\begin{array}{l}\text { A telenovela, considerada uma das mais engraçadas de } \\
\text { sua época, foi vendida para mais de dez países e era } \\
\text { protagonizada por dois "trambiqueiros" que faziam de } \\
\text { tudo para sobreviver e bancar a filha de um deles no } \\
\text { exterior. Naná e Jerônimo Machado são duas pessoas } \\
\text { "boas", que não conseguem encontrar outra forma de } \\
\text { ganhar a vida. A trama se passa na cidade de São Paulo e } \\
\text { conta o cotidiano dos anos } 1980 \text {. }\end{array}$ \\
\hline $\begin{array}{l}\text { Tieta do } \\
\text { Agreste }\end{array}$ & 1989/90 & $\begin{array}{l}\text { Rede } \\
\text { Globo }\end{array}$ & $\begin{array}{l}\text { Aguinaldo } \\
\text { Silva, } \\
\text { Ana M. } \\
\text { Moretzsohn } \\
\text { e Ricardo } \\
\text { Linhares }\end{array}$ & $\begin{array}{l}\text { Inspirada na obra de Jorge Amado, a telenovela se inicia } \\
\text { com a jovem Tieta fugindo do conservadorismo do seu } \\
\text { pai, indo para outro estado distante. Depois de anos ela } \\
\text { reaparece na pequena cidade onde foi humilhada por } \\
\text { seu pai, decidida a se vingar de todos que a maltrataram. }\end{array}$ \\
\hline $\begin{array}{l}\text { Despedida } \\
\text { de Solteiro }\end{array}$ & $1992 / 93$ & $\begin{array}{l}\text { Rede } \\
\text { Globo }\end{array}$ & $\begin{array}{l}\text { Walter } \\
\text { Negrão }\end{array}$ & $\begin{array}{l}\text { O enredo se passa na fictícia cidade de Remanso, onde } \\
\text { três amigos se reuniram para a despedida de solteiro } \\
\text { de João Marcos. Entretanto, a festinha termina numa } \\
\text { cachoeira, quando uma das jovens que estava com o } \\
\text { grupo é assassinada. O decorrer da trama gira em torno } \\
\text { das acusações e injustiças relacionadas a esse crime. } \\
\text { A telenovela foi vendida para onze países, dentre eles } \\
\text { Portugal, onde fez muito sucesso. }\end{array}$ \\
\hline O Clone & $2001 / 02$ & $\begin{array}{l}\text { Rede } \\
\text { Globo }\end{array}$ & Glória Perez & $\begin{array}{l}\text { A equipe da telenovela temeu a boa aceitação da } \\
\text { trama, visto que a estreia aconteceu pouco depois dos } \\
\text { atentados terroristas de } 11 \text { de setembro em Nova lorque } \\
\text { e Washington, já que a telenovela trazia um drama entre } \\
\text { personagens muçulmanos. Apesar disso, é um sucesso } \\
\text { que inicia com a grande paixão de Lucas por uma } \\
\text { muçulmana, Jade, os quais planejavam um futuro juntos. } \\
\text { Porém, nada foi como planejado, até que se passam } 20 \\
\text { anos, e o clone de Lucas (Leandro), feito pelo geneticista } \\
\text { Albieri, criado à sua revelia, aparece e se apaixona por } \\
\text { Jade, o que alimenta toda o enredo. }\end{array}$ \\
\hline
\end{tabular}




\begin{tabular}{|c|c|c|c|c|}
\hline $\begin{array}{l}\text { Flor do } \\
\text { Caribe }\end{array}$ & 2013 & $\begin{array}{l}\text { Rede } \\
\text { Globo }\end{array}$ & $\begin{array}{l}\text { Walther } \\
\text { Negrão }\end{array}$ & $\begin{array}{l}\text { Três crianças (Ester, Cassiano e Alberto) se conhecem } \\
\text { e constroem uma linda amizade na pequena cidade de } \\
\text { Vila dos Ventos, no litoral do Rio Grande do Norte. Anos } \\
\text { mais tarde, Alberto, herdeiro da família, deixa a cidade } \\
\text { para estudar. Enquanto isso, Ester e Cassiano constroem } \\
\text { um romance verdadeiro. Quando Alberto volta para a } \\
\text { cidade, tenta acabar com o casal, armando um plano } \\
\text { para Cassiano ser dado como morto. Seis anos depois do } \\
\text { desaparecimento, no entanto, ele volta disposto a recu- } \\
\text { perar tudo o que perdeu. }\end{array}$ \\
\hline Chiquititas & 2013 & SBT & $\begin{array}{c}\text { Íris Abrava- } \\
\text { nel }\end{array}$ & $\begin{array}{l}\text { Telenovela infantil de grande sucesso de uma emissora } \\
\text { que não é reconhecida por suas novelas. A recriação de } \\
\text { Chiquititas, baseada na telenovela que foi fenômeno nos } \\
\text { anos 1990, conta a história de Gabriela, uma jovem que } \\
\text { sofre várias perdas num espaço curto de tempo, o que } \\
\text { a deixa profundamente abalada. Mesmo com o drama } \\
\text { familiar, José Ricardo, seu pai, funda o orfanato Raio de } \\
\text { Luz, um lugar que acolhe crianças abandonadas. }\end{array}$ \\
\hline Velho Chico & 2016 & $\begin{array}{l}\text { Rede } \\
\text { Globo }\end{array}$ & $\begin{array}{c}\text { Benedito } \\
\text { Ruy Barbosa }\end{array}$ & $\begin{array}{l}\text { A trama se inicia no Nordeste brasileiro, na década de } \\
1960.0 \text { coronel Jacinto já comanda quase tudo naquelas } \\
\text { terras, porém ainda se interessa pelas terras do capitão } \\
\text { Rosa. Entretanto, ele é um dos poucos por ali que tem } \\
\text { coragem de enfrentar a figura do "Todo-Poderoso". Com } \\
\text { isso, inicia-se um duelo que atravessa gerações e se este- } \\
\text { nde até a atualidade, com um épico esteticamente revo- } \\
\text { lucionário, abordando temas como sustentabilidade, } \\
\text { misticismo e poder. }\end{array}$ \\
\hline $\begin{array}{c}\text { Haja Cora- } \\
\text { ção }\end{array}$ & 2016 & $\begin{array}{l}\text { Rede } \\
\text { Globo }\end{array}$ & Daniel Ortiz & $\begin{array}{l}\text { A telenovela é uma releitura de um sucesso dos anos } \\
1980 \text { ("Sassaricando"). Tancinha é uma jovem que desde } \\
\text { os } 15 \text { anos namora seu vizinho Apolo. Seu grande sonho } \\
\text { é casar-se com ele. No entanto, pouco tempo antes de } \\
\text { realizar esse sonho, Beto ("mauricinho") decide que quer } \\
\text { conquistar Tacinha e faz de tudo para entrar em sua vida. }\end{array}$ \\
\hline
\end{tabular}

Fonte: Banco de Imagens e catalogação da Rede Globo e SBT, 2016.

Como mencionado, tais obras foram observadas a partir de análise de conteúdo, que segundo Bauer (2002, p. 191), consiste em "uma técnica para produzir interferências de um texto focal para seu contexto social de maneira objetivada". Tal análise exige objetivamente a formulação de categorias de análise e registro. Para tanto, selecionaram-se (Quadro 2) alguns dos atributos de análise da imagem de destinos turísticos apontados por Santana (2009), para subsidiar essa necessidade. Isso por reconhecer que os atributos apontados pelo autor podem dialogar diretamente com a formação da imagem e do imaginário turístico que se quis tratar nesta pesquisa.

Quadro 2 - Adaptação de Atributos de imagens aplicadas aos diferentes atores do destino

\begin{tabular}{|c|c|c|c|}
\hline Qualidade da Experiência: & Meio ambiente e economia: & Atrações/ Atividades: & Relaxamento e fuga: \\
\hline $\begin{array}{c}\text { Hospedagem } \\
\text { Transporte }\end{array}$ & $\begin{array}{c}\text { Plimaias } \\
\text { Restauração e oferta } \\
\text { alimentar }\end{array}$ & $\begin{array}{c}\text { Variedade da fauna e da flora } \\
\text { Lugares de interesse histórico } \\
\text { V cultural }\end{array}$ & Atividade de lazer \\
População e vida rural & & $\begin{array}{c}\text { Relaxar físico e men- } \\
\text { talmente } \\
\text { Iniciar aventuras }\end{array}$ \\
\hline
\end{tabular}

Fonte: Adaptação de Santana (2009, p.114)

Cada uma das 4 categorias de análise selecionadas (em negrito nas colunas) 
subdividiu-se em categorias de registro, tendo no processo de observação a investigação sobre a presença e a forma como cada uma delas surge nas cenas das telenovelas. Isso permitiu a sintetização de elementos que sitiaram quadros de imagem e criaram imaginários difundidos pelas 8 obras televisivas.

\section{ANÁLISE DOS RESULTADOS: TURISTANDO NA TV}

A análise a seguir ocorreu utilizando os itens destacados anteriormente, reconhecendo-os como categorias que puderam ser observadas nas cenas captadas, servindo de elementos reflexivos sobre a imagem e o imaginário acerca do destino turístico Rio Grande do Norte. Porém, antes de adentrar nos atributos, faz-se necessário contextualizar as telenovelas selecionadas.

\section{IDENTIFICAÇÃO DAS NOVELAS E DE CENÁRIOS}

Cambalacho (1986 - Imagem 01): a telenovela divulga a cidade de Natal-RN no último capítulo por meio da personagem mais popular da trama - Tina Pepper, mostrando-a na piscina do Hotel Escola Barreira Roxa, localizado na Via Costeira de Natal. Em seguida, a personagem passeia de buggy, registrando a Igreja de Pedra da Praia da Redinha e os pescadores. Depois, a personagem surge nas Dunas de Jenipabu (primeira aparição de tráfego de buggy em telenovelas).
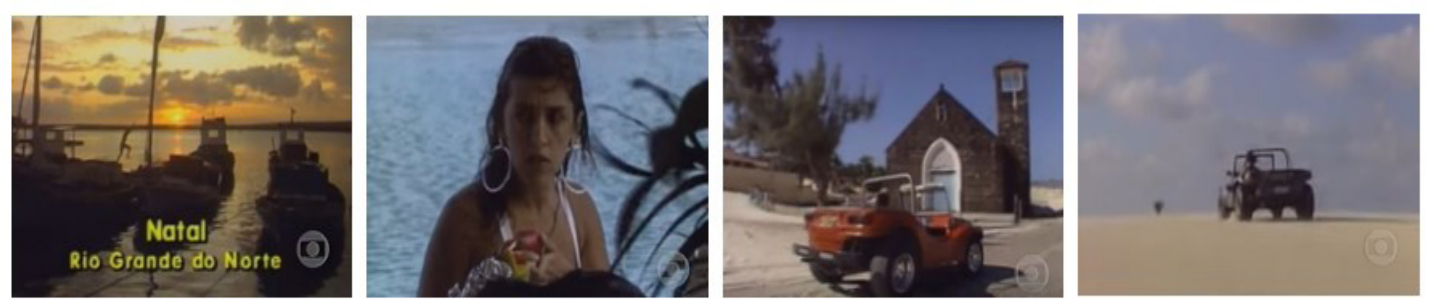

Imagem 01 - Imagens da telenovela Cambalacho (1986)

Fonte: Rede Globo de Televisão (2016)

Tieta do Agreste (1989 - Imagem 02): filmada nas Dunas de Jenipabu (Extremoz - Grande Natal), uma das cenas mostra "cabritas" pastando, fazendo alusão ao apelido da personagem, que se despedia do seu vilarejo (o cenário remete ao interior da Bahia e não ao destino RN). Em alguns momentos da telenovela, as cenas nas dunas são retomadas, não apenas com Tieta, mas também com outros personagens, como no clipe reproduzido na própria telenovela, intitulado de "Uma nova mulher" (tema da personagem Tonha, da atriz Yoná Magalhães), que foi exibido nos últimos capítulos do de uma das novelas de maior audiência da TV Brasileira. 

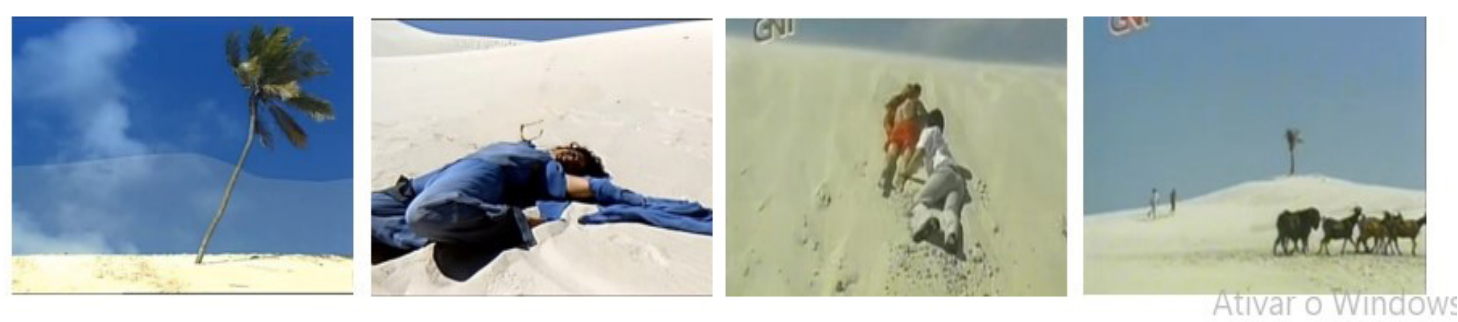

Imagem 02 - Imagens da telenovela Tieta do Agreste (1989) Fonte: Rede Globo de Televisão (2016)

Despedida de Solteiro (1992 - Imagem 03): a sequência de cenas da telenovela se passa no último capítulo (alta audiência), retratando a lua de mel de dois dos personagens principais, mostrando vários cenários do RN, como a Praia do Forte, Morro do Careca, Praia de Jenipabu (descendo de esquibunda), Lagoa de Jenipabu e dunas, Via Costeira, passeio de buggy, além das dependências do Hotel Imirá, mostrando a fachada e o interior do meio de hospedagem, com os personagens tomando banho de piscina.
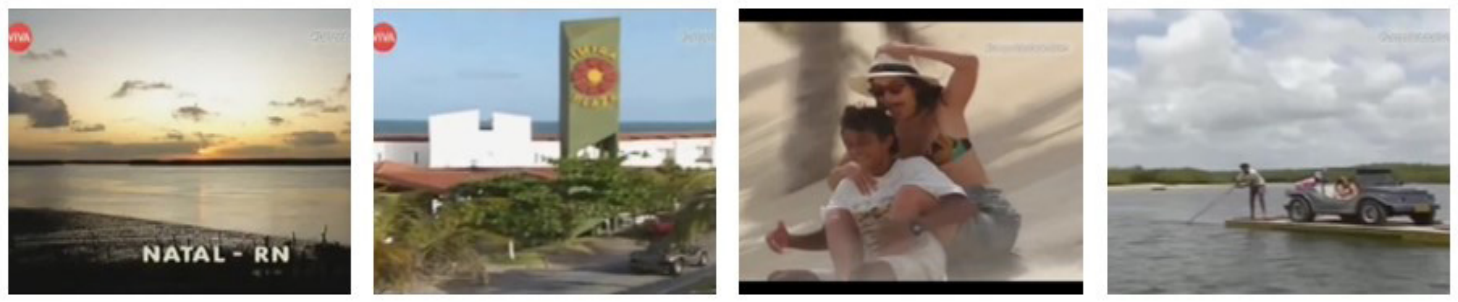

Imagem 03 - Imagens da telenovela Despedida de Solteiro (1992) Fonte: Rede Globo de Televisão (2016)

O Clone (2001 - Imagem 04): a telenovela fazia uma ponte entre Brasil e Marrocos. No capítulo final da ficção (também conhecida como a primeira grande novela do século XXI - visto seu sucesso), as dunas de Jenipabu foram utilizadas para representar o deserto africano. Não ficou evidente o destino RN no enredo, mas ocorreu divulgação da locação em diversos programas de TV e revistas eletrônicas, havendo uma apropriação da cultura marroquina em passeios temáticos (em dromedários e com roupas de sheik) pelas dunas até os dias atuais.
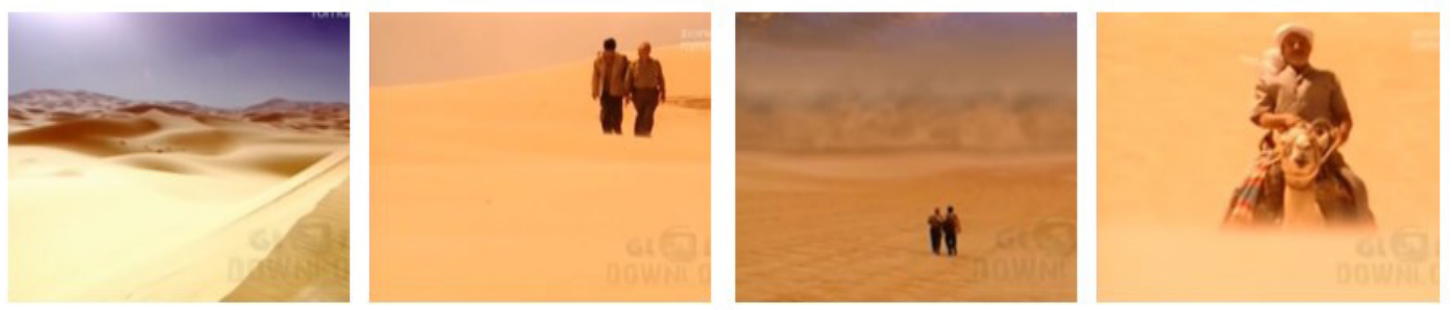

Imagem 04 - Imagens da telenovela O Clone (2001) Fonte: Rede Globo de Televisão (2016)

Flor do Caribe (2013 - Imagem 05): pelo fato de o enredo da telenovela se passar numa cidade caiçara fictícia do $\mathrm{RN}$, as cenas exibem as principais praias do Estado: Praia do Madeiro e Pipa (Tibau do Sul), Jenipabu (Extremoz), e o litoral de Baía Formosa. Todas essas imagens compõem uma cidade imaginária próxima à cidade de Parnamirim (Grande Natal). Mostra-se ainda a Base Aérea de Parnamirim, salinas do RN, e no interior, a Mina 
Brejuí (extração de scheelita no município de Currais Novos), representando as minas de diamantes da trama. Uma informação importante e contraditória é que o título da telenovela remete a outro destino internacional (Caribe), não fazendo menção ao estado ou ao Brasil.
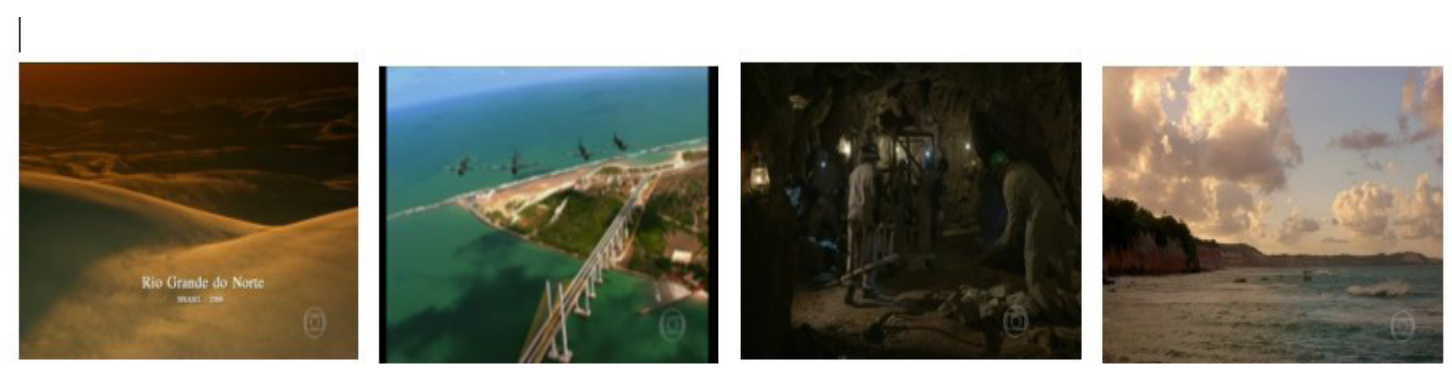

Imagem 05 - Imagens da telenovela Flor do Caribe (2013)

Fonte: Rede Globo de Televisão (2016)

Chiquititas (2013 - Imagem 06): divulga em cenas finais da trama a lua de mel de dois dos personagens principais - que ficam hospedados no Serhs Grand Hotel (Via Costeira) em Natal e onde há práticas de lazer das crianças da trama. Eles passeiam de buggy, mostrando a Praia de Jenipabu (Extremoz), visitam o Forte dos Reis Magos, o Cajueiro de Pirangi (Parnamirim), brincando de esquibunda e fotografando na Árvore do Amor (município de Maxaranguape).
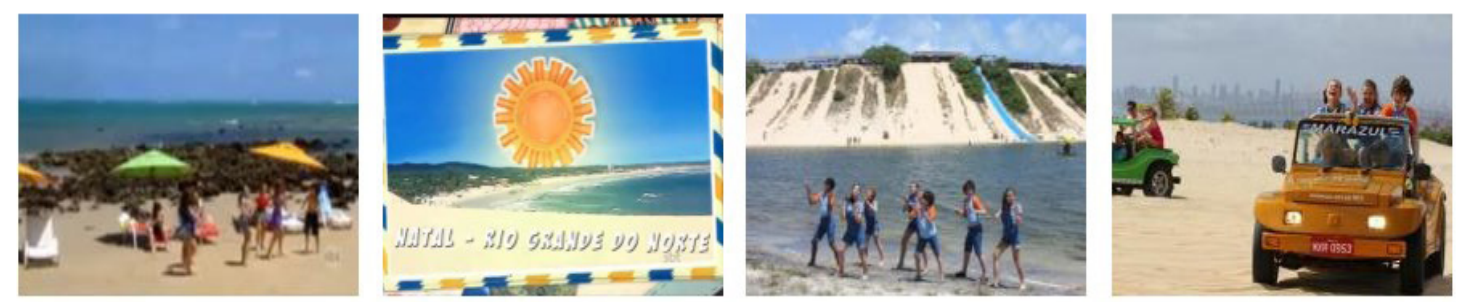

Imagem 06 - Imagens da telenovela Chiquititas (2013)

Fonte: Sistema Brasileiro de Televisão - SBT (2016)

Velho Chico (2016 - imagem 07): as cenas da primeira fase da telenovela (primeira semana em horário nobre) mostram fazendas de algodão, que são a fonte de renda para os assentados que vivem na fictícia cidade onde a trama se passa. Porém, em nenhum momento fica clara na exibição a localização exata do destino (na trama seria o sertão baiano). As cenas foram gravadas no interior do RN, no distrito de Baraúna.
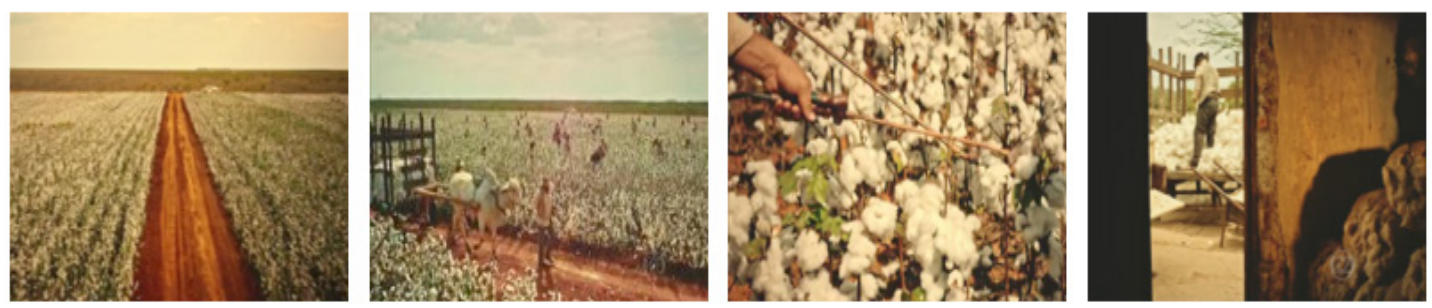

Imagem 07 - Imagens da telenovela Velho Chico (2016)

Fonte: Rede Globo de Televisão (2016)

Haja Coração (2016 - Imagem 08): o último capítulo exibe em alguns segundos curtos flashes da Grande Natal, fazendo menção ao lugar tranquilo e feliz onde a problemática 


\section{TURISM曲}

D0I: 10.14210/RTVA.V21N1.P02-22

personagem da Tamara vai descansar e fazer um trabalho filantrópico. Na curta aparição, destaca-se a Praia da Redinha, com vista para a Ponte Newton Navarro, as dunas de Jenipabu, o passeio de buggy na orla e a vista aérea da Praia do Forte e a Fortaleza dos Reis Magos.
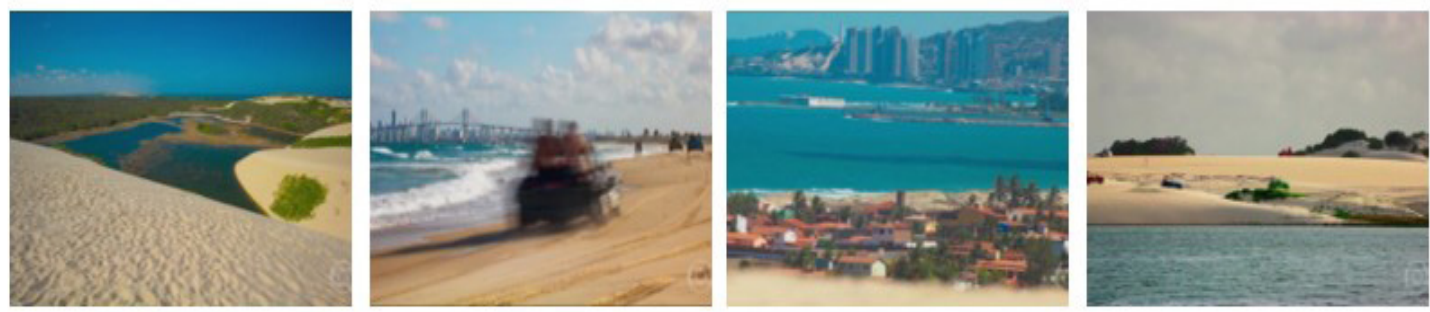

Imagem 08 - Imagens da telenovela Haja Coração (2016) Fonte: Rede Globo de Televisão (2016)

Apesar das cenas mostrarem imagens do estado, algumas não constroem objetivamente o imaginário do RN, porque não fazem referência ao destino, e sim a outros lugares, como as telenovelas Tieta do Agreste, O Clonee Velho Chico-mesmo reconhecendo que a vinda dessas equipes para gravação permite a construção de conteúdos para matérias jornalísticas e publicidade em redes sociais. Cita-se também a telenovela Haja Coração, que mostrou turísticas paisagens em poucos segundos, porém sem deixar claro o nome exato do destino; a personagem apenas dizia que viajara para o Nordeste. A cena ainda faz referência a um orfanato (pois o fim da personagem é cuidando de crianças), ficando claro que ele está no mesmo destino nordestino para onde ela viajou. Porém, não foi isso que aconteceu, a atriz não chegou a viajar para o Rio Grande do Norte, sendo a cena gravada numa locação do Rio de Janeiro. Vale enfatizar que em 06 das 08 telenovelas em que cenas se passaram no destino RN, tais imagens eram exibidas no último capítulo, o que garante maior audiência e remete sempre a um clima feliz e apoteótico de prazer - o que deixa clara uma preocupação estratégica de marketing das secretarias estaduais e municipais captadoras ou que apoiam as iniciativas das emissoras.

\section{APRESENTAÇÃO DE IMAGENS E IMAGINÁRIOS TURÍSTICOS CONTIDOS EM CENAS NOVELÍSTICAS}

Inspirando-se nas categorias apontadas no Quadro 2, buscou-se selecionar cenários, atrativos, serviços, equipamentos e motivações criadoras do imaginário sobre os destinos RN. Destacam-se na categoria de análise qualidade da experiência as seguintes categorias de registro:

Hospedagem (Imagem 09): na telenovela Despedida de Solteiro, mostra-se a parte exterior do Hotel Imirá Plaza, numa área onde se localizam alguns dos melhores hotéis de luxo de Natal (Via Costeira). Sobre a infraestrutura geral do hotel, os personagens aparecem na recepção de maneira rápida, onde são recebidos para fazer o check-in em um lugar arejado. Em seguida, os personagens caminham até o quarto, exibindo em cena um funcionário fardado carregando as bagagens, enquanto eles apreciam o hotel tipicamente de praia. Logo após, o casal aparece na área da piscina conversando e desfrutando de área sofisticada. Na telenovela Chiquititas, o casal está hospedado no Hotel Serhs (também via Costeira) e apenas a piscina é exibida - uma área de lazer muito sofisticada e com vista para o Morro do Careca. Em Cambalacho, da mesma forma, a personagem apenas aparece na área da piscina e, após tomar 
um drink no bar molhado do Hotel Barreira Roxa - também localizado na Via Costeira. Ou seja, a imagem dos meios de hospedagem do RN concentra-se no litoral e em hotéis de médio ou grande porte em áreas isolada e de aparência exclusiva, como é a Via Costeira.
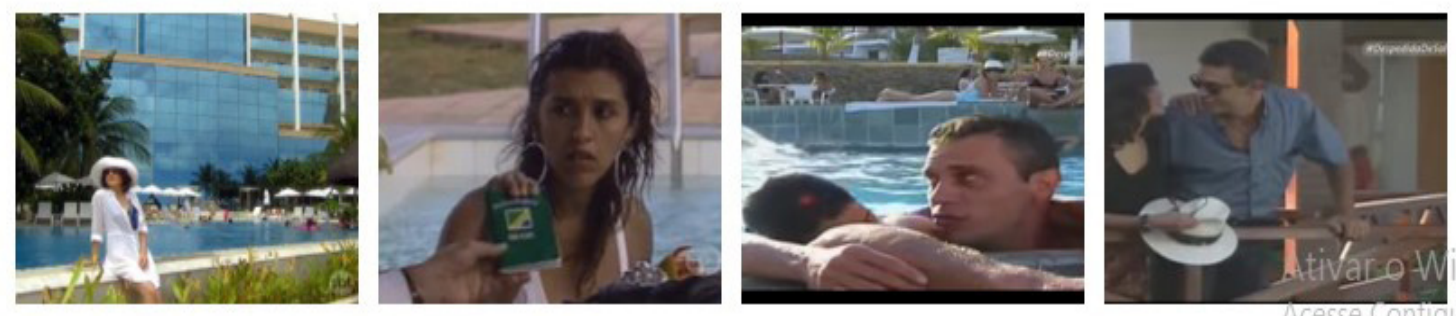

Imagem 09 - Imagens da hospedagem nas telenovelas Fonte: Rede Globo de Televisão (2016)

Restauração e oferta alimentar: na maioria das telenovelas a restauração e a oferta a alimentar são representadas com os personagens tomando água de coco, sendo o alimento que mais aparece nas cenas que divulgam o RN. Na telenovela que se passa no RN (Flor do Caribe), existe um quiosque à beira-mar que recebe turistas nacionais e estrangeiros com um guia de turismo auxiliando e traduzindo sempre que necessário. Nesse quiosque são comercializados pratos à base de frutos do mar, como a caranguejada, que é mencionada nas primeiras cenas da telenovela. Há também turistas (Despedida de Solteiro) preparando de maneira rudimentar um peixe por eles pescado (fogueira à beira de Lagoa de Jenipabu). Os personagens que representam os nativos geralmente também aparecem comendo peixe, mas o tipo e a forma de preparo não são destacados. Restaurantes não são observados em cena. Em nenhum momento há referência ao camarão ou à ginga com tapioca, que são marcas deste destino litorâneo, ou à carne de sol típica do interior do estado. Ou seja, as cenas convidam a uma visão de experiências de alimentação simples, barata e à base de pescado, mas não mostram diferenciais gastronômicos do destino.

Transporte (Imagem 10): o transporte retratado nas telenovelas é basicamente o buggy (Cambalacho, Flor do Caribe, Despedida de Solteiro, Haja Coração). Ele é utilizado tanto para passeio individual dos personagens, como também é apontado como fonte de renda e meio de transporte de personagens que interpretam moradores. Barcos de pesca e a exótica balsa que transporta buggies em Barra do Rio (Extremoz) também aparecem em algumas telenovelas, a exemplo de Flor do Caribe. Percebe-se claramente que existe uma relação entre o imaginário construído pelas telenovelas e a informação de que o passeio de buggy (inclusive com uso de balsa rústica) de fato é o mais procurado e realizado no destino $\mathrm{RN}$ - sendo essas aparições nas telenovelas possivelmente propulsoras desse roteiro.
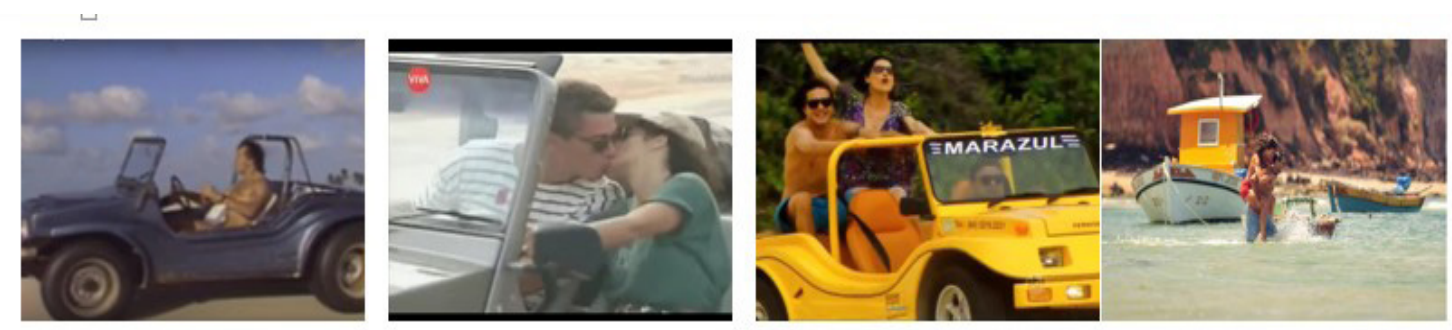

Imagem 10 - Imagens de transportes nas telenovelas

Fonte: Rede Globo de Televisão e SBT (2016) 
a) Vida noturna: a "badalação" pouco aparece nas obras, apesar de uma das cenas mostrá-la a partir de um show realizado pela personagem Tina Pepper numa boate, que supostamente seria em Natal. No entanto, a cena não mostra a infraestrutura da casa noturna, sendo exibidas apenas partes curtas de um clipe. $\mathrm{O}$ que se vê em determinado momento são pessoas (algumas celebridades) muito amigáveis se abraçando e cumprimentando a personagem, e em outro momento aparece o show com a personagem cantando e dançando. Em outra telenovela, Flor do Caribe mostra-se um casal (é recorrente um imaginário do RN romântico), namorando na praia à noite. A cena cria uma atmosfera de lugar tranquilo e inóspito - quando as pessoas se confraternizam à noite, isso acontece em pequenos bares praieiros e rústicos. O que se percebe é que, turisticamente, a imagem novelística pouco imprime atrativos noturnos consolidados, apesar de destacar repetidamente na segunda novela o lual a dois numa atmosfera romântica, segura e tranquila.

Com relação à categoria de análise Meio ambiente e economia, destaca-se:

b) Clima:em todas as cenas em que os personagens visitam ou moram no Rio Grande do Norte, o clima é sempre tropical, aparentemente de muito sol e altas temperaturas. Em quase nenhum momento foi detectado o clima nublado (apenas em algumas cenas de Flor do Caribe - no correr do cotidiano da cidade fictícia), estando as atividades de lazer sempre associadas a esse clima no litoral, nunca no interior do estado.

c) Praias: o RN, de maneira geral, é divulgado como lugar de praias paradisíacas, porém, por meio das telenovelas, esse traço do destino é ainda mais enaltecido, sendo então apresentado o segmento de motivação SOL E MAR. Esses cenários de praia retratam, em geral, casais apaixonados (Cambalacho, Tieta, Despedida de Solteiro, Flor do Caribe) se utilizando de um enredo romântico e sensual como um destino de encontros amorosos. Em apenas uma das telenovelas as praias são divulgadas como um destino de férias para as crianças (Chiquititas), remetendo ao turismo recreativo ou familiar. Ainda assim, as crianças estão no RN graças aos personagens adultos principais que o escolhem como destino de lua de mel.

d) Variedade da flora: na telenovela Chiquititas, os personagens também passeiam pelo Cajueiro de Pirangi (município de Parnamirim). Na cena o guia de turismo fala sobre o atrativo e os personagens apreciam a vista do mirante. Em outra tomada, eles visitam ainda a Árvore do Amor e se impressionam pelo formato da planta - isso denota tentativa de criar o imaginário de destino com vegetação tropical e de certo exuberante com mata de restinga em alguns momentos, e Mata Atlântica de transição em outros. Percebe-se pouca associação do estado a um bioma bastante presente na região, a caatinga - apenas na novela Velho Chico, nos cenários de plantação de algodão - mas que a trama se passa no interior da Bahia.

e) Lugares de interesse histórico cultural (Imagem 11): em Cambalacho foi exibida a Igreja de Nossa Senhora dos Navegantes, conhecida popularmente como Igreja de Pedra, mostrando a parte exterior da edificação, num momento de passeio pela Praia da Redinha (Natal-RN). A Fortaleza dos Reis Magos surge em cenas panorâmicas, e apenas na telenovela Chiquititas é possível visualizar a sua parte interna. Na oportunidade, o personagem da telenovela ainda conta um pouco sobre a história do local. Observa-se também a Base Aérea de Parnamirim, que aparece constantemente na telenovela Flor do Caribe, já que os 
personagens são pilotos. Além disso, destaca-se a Mina Brejuí, que é um atrativo histórico importante do Seridó Potiguar, mas que na tela não foi apresentado como tal. Em geral são poucos os atrativos históricos e culturais explorados, principalmente os presentes no centro histórico de Natal (os personagens normalmente se concentram no litoral). Mas é importante ressaltar positivamente certa descentralização espacial e de períodos históricos, visto que se ressaltou, mesmo que indiretamente, uma região distante da capital (mina do município de Currais Novos), além de fatos da fundação da cidade de Natal, da sua participação na $2^{\text {a }}$ Guerra Mundial e a expressão de fé do pescador (personagem importante na tradição popular).
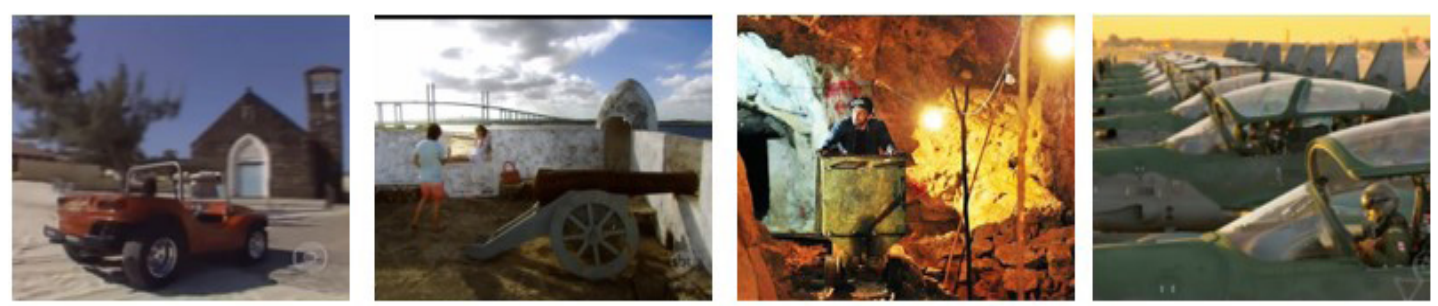

Imagem 11 - Imagens de lugares de interesse histórico-cultural da telenovela Fonte: Rede Globo de Televisão (2016)

e) Populações e vida rural: as cenas de Velho Chico mostram o trabalho na fazenda de algodão onde os personagens trabalham duramente, a fim de conseguir seu sustento, porém essa telenovela não retrata a cena gravada como sendo no RN, e sim no estado da Bahia (mas matérias jornalísticas sobre o início da novela ajudaram a criar esse imaginário de população humilde e trabalhadora). No que se refere aos momentos em que se evidencia o RN, os moradores aparecem como pessoas sorridentes, trabalhando como pilotos da Aeronáutica, salineiros e grandes empresários (Flor do Caribe), mas principalmente como pescadores (Flor do Caribe e Cambalacho), bugueiros (Flor do Caribe e Chiquititas), proprietários de quiosques (Despedida de Solteiro), guias de turismo (Chiquititas). Percebese claramente a busca por apresentar imagens e consolidar imaginários de um povo simples e hospitaleiro - principalmente com na oferta de serviços turísticos.

Por meio da categoria de análise Atrações/ Atividades, pode afirmar que há:

f) Atividades de lazer: as crianças da telenovela Chiquititas que participam dos clipes filmados no RN fizeram um pequeno tour pela grande Natal. No início de um dos clipes, surge o Relógio do Sol, localizado na Praia de Areia Preta, e o Parque da Cidade ambos de forma bastante rápida. Logo em seguida, as crianças aparecem se divertindo na Praia de Pirangi, enquanto dançam e cantam. Um clipe semelhante é gravado no barco "Marina Badauê", onde as crianças também são filmadas, enquanto fazem o mergulho nos parrachos de Pirangi (Parnamirim-RN). O casal que está em lua de mel realiza o passeio de buggy e visita o Cajueiro de Pirangi, o Forte dos Reis Magos, a Árvore do Amor e anda nos dromedários das Dunas de Jenipabu. Despedida de Solteiro é outra telenovela que mostra um casal que foi passar a lua de mel em Natal. Em uma das cenas, eles aparecem praticando o esquibunda e depois passeando de buggy pelas Dunas de Jenipabu. Ressalta-se mais uma vez que esse passeio foi exibido em praticamente todas as telenovelas e, sem dúvida, é a atividade mais divulgada nas cenas gravadas e exibidas do Rio Grande do Norte. Para além disso, destacam-se a concentração das atrações e as atividades de lazer no litoral e com atrativos naturais, focando-se nitidamente no turismo de sol e praia. 


\section{TURISM母}

Quanto à categoria de análise Relaxamento e fuga, se percebe:

g) Quebra de rotina: dos casais que estão passando a lua de mel no RN, na telenovela Despedida de Solteiro, os personagens saem do hotel em busca de um lugar mais tranquilo e sem muito estrutura. Em seguida, aparecem na lagoa de Jenipabu, estando a esposa tomando banho nua às suas margens, veiculando o destino a um lugar exótico e erótico. Essa conotação também ocorre em cenas de Tieta passeando pelas dunas, apresentando inclusive a personagem como uma nova mulher (Tonha), relembrando as humilhações que viveu, e agora livre e bela - com tomadas sensuais dela rolando prazerosamente nas Dunas de Jenipabu. Ainda é possível observar em outras duas telenovelas os casais se beijando deitados sobre as dunas. Mesmo com o destino RN investindo nas promoções de divulgação como um lugar para família, o imaginário criado por meio das telenovelas pode ser de um lugar paradisíaco e isolado, enfatizando a sensualidade tropical. Ainda sobre Despedida de Solteiro, o casal aparece tratando e fritando peixe pescado por eles na lagoa, transmitindo a imagem de lugar inóspito e por vezes sem infraestrutura, principalmente pelo fato de eles dialogarem sobre a impossibilidade de se fazer uma ligação telefônica.

h) Relaxar física e mentalmente (Imagem 12): em Despedida de Solteiro, enquanto a esposa está preocupada com a empresa, o marido tenta fazer com que ela esqueça as preocupações deixadas em casa, mostrando os atrativos que o destino tinha a oferecer, levando-a para a piscina do hotel, para a Lagoa de Jenipabu e para praticar o esquibunda. Em Tieta, a personagem desliza sua canga sobre o vento, denotando estar livre de obrigações e tomada por um momento de ócio sobre as dunas. Em Cambalacho, a personagem viaja para o RN com o propósito de se refazer de uma decepção amorosa. Essa menção à liberdade, é expressa em praticamente todas as aparições, buscando convidar o expectador que entende o que vê como destino RN a imaginar um lugar de "desligamento" do cotidiano de trabalho.
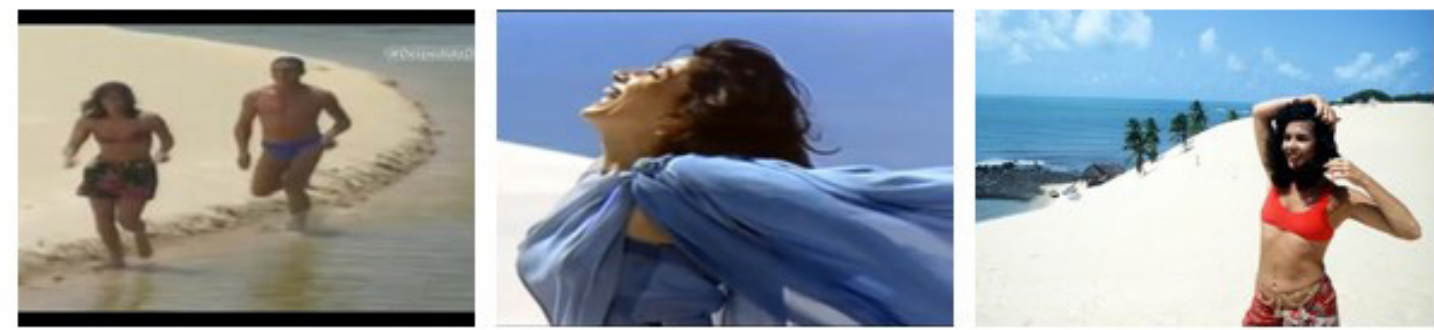

Imagem 12 - Imagens do relaxar física e mentalmente nas telenovelas Fonte: Rede Globo de Televisão (2016)

i) Iniciar aventuras (Imagem 13): na maioria das cenas, repetem-se os passeios "com emoção" em buggies pelas Dunas de Jenipabu. Esses passeios já fazem parte do imaginário sobre o RN, pois (como já mencionado) na maioria das telenovelas eles são realizados pelos personagens. Outras opções de atividades de aventuras são o mergulho em Maracajaú e o esquibunda, que atraem a atenção de alguns turistas que visitam o litoral do Rio Grande do Norte - e isso é expresso nas telenovelas mais recentes (Chiquititas). O imaginário de aventura mais uma vez se dá em um cenário litorâneo, com a presença de atividades em meio à natureza praieira. 

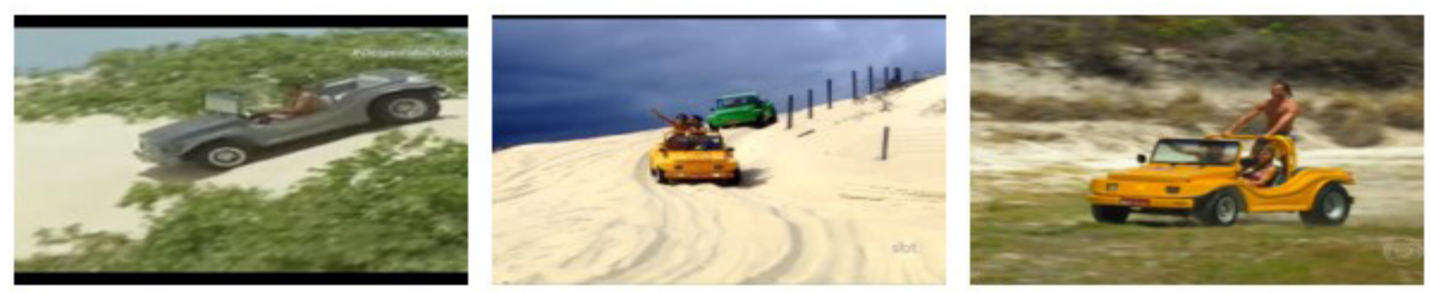

Imagem 13 - Imagens de aventuras nas telenovelas

Fonte: Rede Globo de Televisão e SBT (2016)

Quando observados a imagem e o imaginário turístico sobre o RN, sendo levado em consideração os enredos das telenovelas analisadas, desenha-se um perfil de turistas que, em sua maioria, seria caracterizado por casais do Sudeste do país que buscam um lugar paradisíaco, com forte apelo para o segmento do turismo sol e praia, com alguns poucos atrativos de aventura e cultural.

\section{CONSIDERAÇÕES FINAIS: CENAS DO PRÓXIMO CAPÍTULO}

$\mathrm{Na}$ busca por sintetizar essa apreciação sobre as obras e os destinos, pode-se observar que apenas nove municípios foram utilizados como set de filmagens, e nem todos foram divulgados como tal. Apesar disso, diferentes regiões do estado foram de alguma forma contempladas (mesmo de timidamente). Destaca-se também que, apesar de algumas telenovelas não apontarem claramente o nome do destino utilizado para o cenário, existe ainda, a partir dessa estratégia, grande visibilidade em outros canais e uso do cenário como atrativo (ainda é possível observar turistas reproduzindo poses da baiana Tieta nas dunas, ou da marroquina Jade nos dromedários de Jenipabu/Extremoz). Para além disso, podese apontar telenovelas que destacaram de forma evidente e impactante o Rio Grande do Norte, como Flor do Caribe, que se utilizou de vários cenários (do litoral e do interior) para criar a fictícia cidade de Vila dos Ventos; e a telenovela Chiquititas, que divulgou o estado como um destino turístico de sol e praia com muitas opções de entretenimento e lazer para adultos, mas também para crianças.

Dentre vários lugares apresentados nas telenovelas, os atrativos que ajudaram na construção do imaginário sobre o RN concentraram em municípios litorâneos do estado (Natal, Extremoz, Parnamirim, Tibau do Sul, Macau, Maxaranguape e Baía Formosa), sendo alguns apresentados como cenário do próprio Rio Grande do Norte. Estes que, sempre quando exibidos, permitiam ao telespectador o imaginário de que se tratava de um atrativo do RN. A maior variedade de atrativos e infraestrutura turística (hotelaria, restauração, praias, atrativos culturais e históricos) se concentrava na capital do estado (Natal). Entretanto, analisando as telenovelas, o atrativo com maior visibilidade é o complexo de Dunas de Jenipabu (passeio de buggy), em Extremoz.

Com relação às motivações, o destino foi exaustivamente (sobretudo nas telenovelas que deixavam claro na trama que se tratava do RN) exibido como cenário de turismo SOL e PRAIA para casais em lua de mel, ou que buscavam o estado como refúgio para encontros amorosos, possibilitando a criação de um imaginário de destino romântico e sensual, já que exibe o clima tropical, solar, com vegetação dunar, coqueirais, falésias, hábitos praieiros sob 
uma atmosfera exótica e quase que inóspita (áreas pouco habitadas), onde vivem pessoas humildes e hospitaleiras.

Esse trabalho convida a refletir sobre a importância do uso das telenovelas para divulgação de destinos. Entretanto, mesmo reconhecendo a importância que foi essa estratégia de marketing para o $\mathrm{RN}$, é preciso reconhecer a necessidade de diversificar a exibição de atrativos e segmentos de destinos desse porte. Destino esse que possui potencial para outras práticas e públicos turísticos, mas que se vende midiaticamente (a exemplo das telenovelas), vinculado a poucas e repetitivas características turísticas.

\section{REFERÊNCIAS}

Acervo o Globo (Brasil). (2015) Inventada em 1925, a TV só pegou mesmo depois da Segunda Guerra Mundial. Disponível em: <http://acervo.oglobo.globo.com/fatos-historicos/inventada-em-1925-tvso-pegou-mesmo-depois-da-segunda-guerra-mundial-9504069>. Acesso em: 03 de Out.

Albernaz, P. (2009). Curta Brasília: a imagem da cidade no olhar do cinema e sua relação com o turismo. Dissertação de Mestrado, Universidade Federal de Brasília, Brasília, DF, Brasil.

Ashton, M. (2003) Parques temáticos: espaços e imaginários. In: GASTAL, S.; Castrogiovanni, A. (Org.). Turismo na Pós Modernidade: (des) inquietações. Porto Alegre: EDIPUCRS, p. 125-129.

Bauer, M. W. (2002) Análise de conteúdo clássica: uma revisão. In: M.W. Bauer \& G. Gaskell (Ed.). Pesquisa qualitativa com texto, imagem e som: um manual prático. Tradução de Pedrinho A. Guareschi. Petrópolis: Vozes. p. 189-217.

Beeton, S. (2005) Film-induced tourism. Nova York: Multilingual Matters.

Brasil. Ministério da Cultura. (2015). A Carta de Pero Vaz de Caminha. Disponível em: <http://objdigital. bn.br/Acervo_Digital/livros_eletronicos/carta.pdf>. Acesso em: 01 de Out.

Brasil. Ministério do Turismo. (2016). A importância da imagem para a divulgação do destino turístico. Disponível em: http://www.turismo.gov.br/ultimas-noticias/5388-a-import\%C3\%A2ncia-da-imagem-paraa-divulga\%C3\%A7\%C3\%A3o-do-destino-tur\%C3\%ADstico.html. Acesso em: 25 de Nov.

Brasil. Secretaria de Comunicação Social. (2014). Pesquisa brasileira de mídia 2015: hábitos de consumo de mídia pela população brasileira. Brasília: Secom.

Brasil. Ministério do Turismo. (2007). Turismo Cinematográfico Brasileiro. Disponível em: http:// www.turismo.gov.br/sites/default/turismo/o_ministerio/publicacoes/downloads_publicacoes/ Cartilha_Cinema.pdf Acesso em: 15 de Mai.

Bucci, E. (1996). Brasil em tempo de TV. São Paulo: Bom tempo.

Castro, M. (2005) Televisão e publicidade: ações convergentes. Porto Alegre: Unisinos.

Cruz, R. (2007). Geografia do turismo: de lugares a pseudo-lugares. São Paulo: Roca.

Cunha, M. (2011) Da imagem à imaginação e ao imaginário: elementos-chave para os estudos em comunicação e cultura. In: BARROS, L. (Org.). Discursos midiáticos: representações e apropriações culturais. São Bernardo do Campo: Universidade Metodista de São Paulo. 
Durand, G. (1996). Campos do imaginário. Lisboa: Instituto Piaget.

Gastal, S. (2005). Turismo, Imagens e Imaginários. São Paulo: Aleph.

Graburn, N.; Gravari-Barbas, M. (2011) Introduction au numéro thématique « Imagined Landscapes of Tourism ». Journal of Tourism and Cultural Change, v. 3, n. 3, p. 159-166.

Hamburger, E. (2005). O Brasil antenado: a sociedade da novela. Rio de Janeiro: Zahar.

Iwashita, C. (2008) Roles of films and television dramas in international tourism: the case of Japanese tourists to the UK. Journal of Travel \& Tourism Marketing, 24 (2/3), 139-151.

Kanyat, L. (2014). Retratos do brasileiro no imaginário equatoriano: um estudo de recepção da telenovela avenida brasil em guayaquil [manuscrito]. São Paulo.

Kotler, P. (2000) Administração de Marketing. São Paulo: Prentice Hall.

Kotler, P.; Fox, K. F. A. (1994). Marketing estratégico para instituições educacionais. São Paulo: Atlas.

Lévy, P. (1998). A ideografia dinâmica rumo a uma imaginação artificial. São Paulo Loyola.

Lopes, M. (2018). Memória e Identidade na Telenovela Brasileira. Disponível em: http://compos.org.br/ encontro2014/anais/Docs/GT12_ESTUDOS_DE_TELEVISAO/templatexxiiicompos_2278-1_2246. pdf. Acesso em: 01 de Jul.

Macionis, N. (2004). Understanding the film-induced tourist. In W. Frost, W. C. Croy, \& S. Beeton (Eds.) Proceedings of the international tourism and media conference (pp. 86-97). Australia: Tourism Research Unit.

Mattos, S. (2010). História da televisão brasileira: uma visão econômica, social e política. 5. ed. Rio de Janeiro: Vozes.

Memória Globo. (2015). Novelas. Disponível em: <http://www.memoriaglobo.com.br>. Acesso em: 03 de out.

Middleton, V. ; CLARKE, J. (2002). Marketing de Turismo: Teoria e Prática. Rio de Janeiro: Elsevier.

Nascimento, F. (2009). Cineturismo. São Paulo: Aleph.

Pereira Neto, F.; Schmidlin, I. (2013). Turismo induzido por filmes: a imagem do Nordeste propagada pelo cinema brasileiro no ponto de vista do estudante de cinema no Ceará. PODIUM: Sport, Leisure and Tourism Review, São Paulo, v. 2, n. 2, p. 01-31, Jul./Dez.

Rede Globo de Televisão. (2016). Banco de imagens. Disponível em: <http://redeglobo.globo. com/>. Acesso em: 25 de Out.

Revista Internacional e Interdisciplinar de Turismo. (2016) Imaginários turísticos. Disponível em: <http://www.viatourismreview.net/Editorial1_PT.php>. Acesso em: 05 de Out.

Santana, A. (2009). Antropologia do turismo: analogias, encontros e relações. São Paulo: Aleph.

SBT de Televisão. (2016). Banco de imagens. Disponível em: <https://www.sbt.com.br/sbtvideos/.> Acesso em: 02 de Out.

Trindade, E. (1999). Merchandising em telenovela: a estrutura de um discurso para o consumo. São 
Paulo. Dissertação de Mestrado em Propaganda, Universidade de São Paulo.

WTTC. (2016). Travel \& tourism economic impact 2015. Disponível em: <zh.wttc.org/-/media/ impact2015/world2015.pdf>. Acesso em: 03 de Out.

Contribuição de cada autor para elaboração

Adrielly Florêncio de Lima: Desenvolvimento do artigo.

Michel Jairo Vieira da Silva: Orientação da pesquisa. 